\title{
and Health (ICASSETH 2019) The Effect of Organic Matter as Plant Media Component to the Growth of Three Ginger Cultivars with Bag Culture Technique
}

\author{
Alfandi Alfandi*, Umi Trisnaningsih, Siti Wahyuni \\ Dept. of Agrotechnology, Agriculture Faculty \\ Universitas Swadaya Gunung Jati (UGJ) \\ Cirebon, Indonesia \\ *alfandi2008@gmail.com
}

\begin{abstract}
This study was conducted to determine the effect of various types of organic materials, as components of the planting medium, on the growth of three ginger cultivars. The experiment was conducted at the Faculty of Agriculture Experimental Garden UGJ, starting from May to July 2019. The materials used in this study were three ginger cultivars, namely Gajah, Merah and Emprit, husk charcoal, sheep manure, and compost of mushroom media planting, NPK fertilizer (15:15:15) while the pesticides used are fungicides and granular insecticides. The experimental design used was a randomized complete design (RCD) with 9 (nine) treatments, consisting of a combination of types of organic matter (compost mushroom media planting, sheep manure, and husk charcoal) with ginger cultivars (Gajah, Merah, and Emprit). Observations were made on the number of shoots that appeared, plant height, number of leaves, and stem diameter. The results showed that the three organic matter used had a significant effect on the growth of the three ginger cultivars. The best growth is obtained from Emprit ginger which is planted in a mixture of soil with sheep manure.
\end{abstract}

Keywords: ginger cultivars Gajah, Merah and Emprit, media planting, organic matter

\section{INTRODUCTION}

Ginger (Zingiber officinale Rosc.) It is a member of the Zingiberaceae family which is commonly used as a raw material for medicines, both traditional and modern medicine [1]. This is because ginger contains volatile oil and volatile oleoresin [2]. Ginger is also a powerful anti-oxidant and can reduce or prevent the formation of free radicals [3]. Jamu, which is a traditional method of Indonesian medicine, requires ginger as a raw material. Besides, ginger is also used as a mixture of drinks and cosmetics, as well as industrial raw materials [4].

The development of the traditional medicine industry and other industries that use ginger as a raw material or additional material, causes the demand for ginger to continue to increase [5]. This increase in demand must certainly be balanced with an increase in domestic ginger production. Therefore, various efforts were made by the Government and also the ginger farmers to increase the production of ginger. Increased production can be done by expanding the planting area, manipulating the microclimate environment, improving cultivation techniques, and developing superior varieties [6]. Another effort that can be done to improve yields is by cultivating ginger in a container or bag culture. This method was introduced by Hepperly et al. in Hawaii 2004 [7]. In this method, ginger is planted in polybags or other containers, making it possible to cultivate ginger on limited land, even in urban areas where agricultural land is not available. The advantage of the bag culture method is that crop maintenance can be done efficiently and intensively. Besides, the condition of the growing media can be controlled, to avoid the attack of wilting. Thus, the input provided is following the needs of plants and plants can be utilized to the maximum

In the bag culture method, planting media is the most determining factor in the success rate of ginger cultivation. This is because in this method the available growth media are quite limited, so the roots cannot grow freely. Root growth will be good if the environment can provide structural support, allow absorption of water, and provide nutrients needed in sufficient quantities [2]. Therefore, the composition of the media used must meet these needs.

Various organic ingredients can be used for growing ginger. Marlina used a mixture of soil with cow manure and husk ash as ginger growing media. While Soeparjono uses bokashi, coconut or cocopeat fibres, and husk charcoal [1]. Other researchers use a mixture of soil, sand, and bokashi with various comparisons [8]. Aidin, Sahiri, and Madauna used soil, sand, chicken manure, and rice straw as material for planting media [2]. These ingredients are used singly or in a mixture.

This study aims to determine the effect of the use of three types of organic material, namely husk charcoal, sheep manure, and mushroom growing media as a component of growing media on the growth of three ginger cultivars.

\section{RESEARCH METHOD}

The study was conducted in the Experimental Garden of the Faculty of Agriculture UGJ. The trial location is at an altitude of $7 \mathrm{~m}$ above sea level. The experiment was carried out from March to July 2019. 
The ingredients used in this study were three ginger cultivars, namely Merah, Gajah, and Emprit. The seeds used to weight about $10 \mathrm{~g}-30 \mathrm{~g}$ with 2-3 buds. Organic materials used are rice husk charcoal, sheep manure, and mushroom growing media waste. Other materials used are soil, NPK fertilizer (15:15:15), Dithane fungicide (for seedling treatment before planting), Furadan insecticide (given when planting), and a 25 $\mathrm{cm} \times 50 \mathrm{~cm}$ polybag.

The planting medium used is a mixture of organic matter with soil in a ratio of $1: 1(\mathrm{v} / \mathrm{v})$. Before being used, the three planting media mixtures were analysed for their nutrient content in the Soil, Plant, Fertilizer and Water Laboratory, Soil Research Institute, Bogor. Each polybag is filled with $8 \mathrm{~L}$ mixed media and planted with one rhizome. Each unit of the experiment consists of 7 (seven) polybags. In the early stages, ginger is stored in a greenhouse, after four weeks later it is transferred to a field that is given $75 \%$ para net shade.

The experimental design used was a completely randomized design (CRD), which consisted of 9 combinations of treatments between organic material (husk charcoal, manure, and mushroom media waste) with three ginger cultivars (Gajah, Merah, and Emprit). All treatments were repeated three times so that there were 27 experimental units. Observations were made on the number of shoots that grow, plant height, number of leaves, and stem diameter. The data obtained were analysed using the $\mathrm{F}$ Test and continued with Duncan's Multiple Range Test at the 5\% level.

\section{RESUltS AND DisCUSSION}

\section{A. Analysis of Planting Media}

Based on the results of the analysis of the Soil, Plant and Water Laboratory (2019), it can be seen in Table 1, that the $\mathrm{pH}$ $\left(\mathrm{H}_{2} \mathrm{O}\right)$ of the three types of planting media is in the neutral category $(6.2-7.6)$, with the lowest $\mathrm{pH}$ being a mixture of soil and husk charcoal. The soil mixture with mushroom compost media has a higher organic $\mathrm{C}$ content compared to the other two mixtures, while the $\mathrm{C} / \mathrm{N}$ ratio is also the highest. The highest organic nitrogen content is also in mixed soil and mushroom compost media. The highest phosphorus $(\mathrm{P})$ and potassium $(\mathrm{K})$ content in the soil mixture and manure while the highest cation exchange capacity in the soil mixture with mushroom compost media (Table 1).
TABLE I. RESUlts of ANALysis of PlANTED MEdia

\begin{tabular}{|c|c|c|c|}
\hline \multirow[b]{2}{*}{ Components } & \multicolumn{3}{|c|}{ Media Type } \\
\hline & $\begin{array}{c}\text { Soil + } \\
\text { Husk } \\
\text { charcoal }\end{array}$ & $\begin{array}{c}\text { Soil + } \\
\text { Manure }\end{array}$ & $\begin{array}{c}\text { Soil }+ \\
\text { Mushroom } \\
\text { Compost }\end{array}$ \\
\hline \multicolumn{4}{|l|}{$\mathrm{pH}:$} \\
\hline $\mathrm{H}_{2} \mathrm{O}$ & 6,20 & 7,20 & 7,60 \\
\hline $\mathrm{KCl}$ & 5,30 & 6,20 & 5,60 \\
\hline \multicolumn{4}{|l|}{ Organic matter } \\
\hline $\mathrm{C}(\%)$ & 3,80 & 4,16 & 5,62 \\
\hline $\mathrm{N}(\%)$ & 0,34 & 0,38 & 0,47 \\
\hline \begin{tabular}{l|l} 
\\
\end{tabular}$/ \mathrm{N}$ & 11,00 & 11,00 & 12,00 \\
\hline \multicolumn{4}{|l|}{$\mathrm{P}_{2} \mathrm{O}_{5}$} \\
\hline \begin{tabular}{l|l} 
& $\mathrm{HCl} 25 \%\left(\mathrm{mg} \mathrm{g}^{-1}\right)$ \\
\end{tabular} & 74,00 & 231,00 & 150,00 \\
\hline \begin{tabular}{l|l} 
& Olsen $(\mathrm{ppm})$
\end{tabular} & 37,00 & 215,00 & 143,00 \\
\hline \multicolumn{4}{|l|}{$\mathrm{K}_{2} \mathrm{O}$} \\
\hline \begin{tabular}{l|l} 
& $\mathrm{HCl} 25 \%\left(\mathrm{mg} \mathrm{g}^{-1}\right)$ \\
\end{tabular} & 172,00 & 327,00 & 67,00 \\
\hline \begin{tabular}{l|l} 
& Morgan $(\mathrm{ppm})$ \\
\end{tabular} & 1531 & 2978 & 564 \\
\hline \multicolumn{4}{|l|}{$\begin{array}{l}\text { Cation } \\
\text { Capacity }\end{array}$} \\
\hline \begin{tabular}{l|l}
$\mathrm{Ca}\left(\mathrm{cmol}_{\mathrm{c}} \mathrm{kg}^{-1}\right)$ \\
\end{tabular} & 6,78 & 9,98 & 21,54 \\
\hline $\operatorname{Mg}\left(\mathrm{cmol}_{\mathrm{c}} \mathrm{kg}^{-1}\right)$ & 2,18 & 3,08 & 6,42 \\
\hline $\mathrm{Na}\left(\mathrm{cmol}_{\mathrm{c}} \mathrm{kg}^{-1}\right)$ & 0,44 & 0,79 & 0,34 \\
\hline Total $\left(\mathrm{cmol}_{\mathrm{c}} \mathrm{kg}^{-1}\right)$ & 12,33 & 18,09 & 25,81 \\
\hline KTK $\left(\mathrm{cmol}_{\mathrm{c}} \mathrm{kg}^{-1}\right)$ & 15,67 & 16,66 & 19,88 \\
\hline $\mathrm{KB}(\%)$ & 79 & $>100$ & $>100$ \\
\hline
\end{tabular}

\section{B. Number of Bud}

The composition of the planting media and ginger cultivars had a significant effect on the number of shots at age 42 and 98 DAP (Days Ater Planting), but did not have a significant effect at age 56-84 DAP. This result can we see in Table 2. When observed in observations of 98 DAP, Emprit cultivars planted on husk charcoal provided the most number of shoots while the least was produced by Gajah cultivars on husk charcoal. Ginger cultivar is more influential compared to the organic material used in this study.

Ginger buds appear on the book, so the number of shoots that appear will depend on the number of books on each seed/rhizome that is planted. In this study, the seeds used had an average of 3 books. Thus it can be understood if the number of shoots that appear ranges from 1-3 buds. However, there are four ginger emprit that have 4 shoots, namely the treatment of emprit which is planted in a mixture of soil and husk charcoal $(\mathrm{H})$.

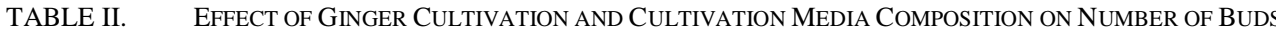

\begin{tabular}{|c|c|c|c|c|c|c|c|c|c|c|}
\hline \multirow{3}{*}{$\begin{array}{c}\text { Treatment } \\
\mathrm{A}=\text { Gajah, mushroom compost media }\end{array}$} & \multicolumn{10}{|c|}{ Number of shoots (fruit) at age } \\
\hline & \multicolumn{2}{|c|}{$42 \mathrm{DAP}$} & \multicolumn{2}{|c|}{$56 \mathrm{DAP}$} & \multicolumn{2}{|c|}{$70 \mathrm{DAP}$} & \multicolumn{2}{|c|}{$84 \mathrm{DAP}$} & \multicolumn{2}{|c|}{$98 \mathrm{DAP}$} \\
\hline & 0.67 & bed & 1.11 & $\mathrm{a}$ & 1.11 & $\mathrm{a}$ & 2.00 & $\mathrm{a}$ & 1.78 & $\mathrm{ab}$ \\
\hline $\mathrm{B}=$ Gajah, husk charcoal & 1.00 & cdef & 1.00 & $\mathrm{a}$ & 1.33 & $\mathrm{a}$ & 1.00 & $\mathrm{a}$ & 1.53 & $\mathrm{a}$ \\
\hline $\mathrm{C}=$ Gajah, manure & 0.33 & $\mathrm{ab}$ & 1.00 & $\mathrm{a}$ & 1.08 & $\mathrm{a}$ & 1.58 & $\mathrm{a}$ & 1.58 & $\mathrm{ab}$ \\
\hline $\begin{array}{l}\mathrm{D}=\text { Merah, mushroom compost } \\
\text { media }\end{array}$ & 1.33 & ef & 1.44 & $\mathrm{a}$ & 1.62 & a & 1.58 & $\mathrm{a}$ & 2.25 & $\mathrm{ab}$ \\
\hline $\mathrm{E}=$ Merah, husk charcoal & 1.22 & def & 1.28 & a & 1.67 & $\mathrm{a}$ & 1.94 & a & 2.81 & $\mathrm{ab}$ \\
\hline $\mathrm{F}=$ Merah, manure & 0.67 & bcd & 1.11 & $\mathrm{a}$ & 1.39 & $\mathrm{a}$ & 1.67 & $\mathrm{a}$ & 2.33 & $\mathrm{ab}$ \\
\hline $\begin{array}{l}\mathrm{G}=\text { Emprit, mushroom compost } \\
\text { media }\end{array}$ & 1.33 & $\mathrm{f}$ & 1.50 & a & 1.64 & a & 2.30 & a & 2.89 & $\mathrm{~b}$ \\
\hline $\mathrm{H}=$ Emprit, charcoal husk & 0.00 & $\mathrm{a}$ & 1.28 & $\mathrm{a}$ & 1.56 & $\mathrm{a}$ & 1.97 & $\mathrm{a}$ & 4.76 & $\mathrm{c}$ \\
\hline $\mathrm{I}=$ Emprit, manure & 1.46 & $\mathrm{f}$ & 1.60 & $\mathrm{a}$ & 1.72 & $\mathrm{a}$ & 1.96 & $\mathrm{a}$ & 2.34 & $\mathrm{ab}$ \\
\hline
\end{tabular}


The results of this study are in line with the results of other studies which show that the number of tillers (shoots) is influenced by the different composition of the planting media $[1,2,9]$. This shows that, although the number of books determines the number of shoots that will grow, the environment will still affect the ability of books to grow buds. In this study, the highest number of shoots by Emprit ginger which was planted in a mixture of soil with husk charcoal. When viewed in the nutrient content, soil mixtures with husk charcoal have lower nutrient content than the other two planting media mixtures (Table 1). However, this media is relatively looser than the other two planting media so that it can store and release water properly and allows optimal air exchange. This condition will allow the rhizome to grow to the maximum bud.

\section{Plant Height}

The composition of the planting media and ginger cultivars significantly affected plant height at all observations except 98
DAP (Days Ater Planting). At 42 DAP, the Merah ginger planted in soil mix with mushroom compost media and husk charcoal was significantly higher than in other treatments although it was not significantly different from Emprit ginger planted in soil mixture with mushroom compost media or manure. However, at the age of 84 DAP, the Emprit planted in mushroom media compost and manure was significantly higher than other treatments except Merah in mushroom media compost, as we see in Table 3 .

The composition of the planting media will affect the growth and quality of ginger yields [1]. This is because good planting media will be able to provide nutrients needed for the rhizomes to grow into new plants. Besides, a good planting medium will provide a good environment for root growth, which further supports the growth of the top of the plant, such as plant height.

TABLE III. EFFECT OF Ginger CULTIVATION AND CUltivation MEdia Composition On Plant Height

\begin{tabular}{|c|c|c|c|c|c|c|c|c|c|c|}
\hline \multirow{2}{*}{ Treatment } & \multicolumn{10}{|c|}{ Plant Height $(\mathrm{cm})$ at age: } \\
\hline & \multicolumn{2}{|c|}{$42 \mathrm{DAP}$} & \multicolumn{2}{|c|}{$56 \mathrm{DAP}$} & \multicolumn{2}{|c|}{$70 \mathrm{DAP}$} & \multicolumn{2}{|c|}{$84 \mathrm{DAP}$} & \multicolumn{2}{|c|}{$98 D A P$} \\
\hline $\begin{array}{l}\mathrm{A}=\text { Gajah, mushroom } \\
\text { compost media }\end{array}$ & 1.33 & $a b$ & 8.12 & bcdef & 9.98 & a & 12.40 & a & 16.25 & a \\
\hline $\mathrm{B}=$ Gajah, husk charcoal & 3.03 & $\mathrm{~b}$ & 6.42 & $a b c$ & 8.86 & $\mathrm{a}$ & 11.58 & $\mathrm{a}$ & 13.01 & $\mathrm{a}$ \\
\hline $\mathrm{C}=\mathrm{Gajah}$, manure & 2.37 & $\mathrm{ab}$ & 7.57 & cdef & 9.05 & $\mathrm{a}$ & 13.65 & $\mathrm{ab}$ & 16.37 & $\mathrm{a}$ \\
\hline $\begin{array}{l}\mathrm{D}=\text { Merah, mushroom } \\
\text { compost media }\end{array}$ & 7.05 & $\mathrm{~cd}$ & 8.74 & cdef & 15.14 & $\mathrm{~b}$ & 19.34 & bcd & 24.41 & bcd \\
\hline $\mathrm{E}=$ Merah, husk charcoal & 8.11 & $\mathrm{~d}$ & 9.49 & def & 16.36 & $\mathrm{bc}$ & 22.27 & cde & 25.73 & cde \\
\hline $\mathrm{F}=$ Merah, manure & 1.12 & $\mathrm{ab}$ & 5.94 & $\mathrm{ab}$ & 7.89 & $\mathrm{a}$ & 12.52 & $\mathrm{a}$ & 16.15 & $\mathrm{a}$ \\
\hline $\begin{array}{l}\mathrm{G}=\text { Emprit, mushroom } \\
\text { compost media }\end{array}$ & 6.42 & $\mathrm{c}$ & 9.82 & $\mathrm{f}$ & 15.20 & $\mathrm{bc}$ & 23.50 & de & 27.00 & de \\
\hline $\mathrm{H}=$ Emprit, charcoal husk & 0.00 & $\mathrm{a}$ & 5.50 & $\mathrm{a}$ & 11.04 & $\mathrm{a}$ & 13.87 & $\mathrm{ab}$ & 18.44 & $\mathrm{a}$ \\
\hline $\mathrm{I}=$ Emprit, manure & 6.66 & $\mathrm{~cd}$ & 13.53 & $\mathrm{~g}$ & 17.84 & $\mathrm{c}$ & 23.74 & $\mathrm{e}$ & 28.37 & $\mathrm{e}$ \\
\hline
\end{tabular}

Note: the average number followed by the same letter in the same column is not significantly different according to Duncan's Multip le Range Test at the 5\% level.

In the Gajah cultivar, all organic matter had almost the same effect on all ages of observation. While in Merah ginger, a mixture of soil and charcoal husks gives a higher plant red compa to the other two organic ingredients. these results are different from previous studies, which stated that the mixture of soil, sand, and manure gave the highest Merah ginger plant compared to other organic materials [2]. In this study, soil mixture with manure provided the best plant height in the Emprit cultivars (Table 3).

The results of this study are in line with the results of other studies in Nigeria which show that the application of manure will increase the parameters of ginger growth, including plant height, which is planted in tropical rainforest regions [10].

\section{Number of Leaves}

Table 4 show that the composition of the planting media and ginger cultivar did not significantly affect the number of leaves at all observations, except at the age of 70 DAP (Table 4).

The difference in plant height that occurs at ages 42 to 64 DAP is not followed by differences in the number of leaves. It is suspected that the difference in plant height is not due to differences in the number of books but due to differences in the length of segments.

Emprit cultivars provide relatively more leaves when compared to the other two cultivars. Meanwhile, the organic material that has the best effect on the number of leaves in Emprit cultivars is manure (11 strands, at 98 DAP). However, in the Gajah and Merah cultivars, manure provides a relatively smaller number of leaves compared to the other two organic materials (Table 4). Allegedly, Emprit root growth is faster than the two other cultivars, so that it can immediately take the nutrients contained in the planting media. Thus Emprit produce relatively more leaves compared to the two other cultivars. The mixture of soil and manure contains nitrogen, phosphorus, and potassium which are relatively higher when compared to the other two planting media mixtures (Table 1). Manure can increase the growth of young ginger. Different types of manure (cow, chicken, and goat manure) have the same effect on the growth and yield of young ginger [11]. 
TABLE IV. EFFECT OF COMPOSITION OF GROWING MEdia AND Ginger Cultivation ON NumBER OF LEAVES

\begin{tabular}{|c|c|c|c|c|c|c|c|c|c|c|}
\hline \multirow{2}{*}{ Treatment } & \multicolumn{10}{|c|}{ Number of leaves (strands) at age: } \\
\hline & \multicolumn{2}{|c|}{$42 \mathrm{DAP}$} & \multicolumn{2}{|c|}{$56 \mathrm{DAP}$} & \multicolumn{2}{|c|}{$70 \mathrm{DAP}$} & \multicolumn{2}{|c|}{$84 \mathrm{DAP}$} & \multicolumn{2}{|c|}{$98 \mathrm{DAP}$} \\
\hline $\begin{array}{l}\mathrm{A}=\text { Gajah, mushroom compost } \\
\text { media }\end{array}$ & 0.67 & a & 2.00 & a & 3.83 & $a b$ & 4.50 & $\mathrm{ab}$ & 6.33 & $a b$ \\
\hline $\mathrm{B}=$ Gajah, husk charcoal & 1.67 & $\mathrm{a}$ & 2.33 & $\mathrm{a}$ & 3.67 & $\mathrm{ab}$ & 4.67 & $\mathrm{ab}$ & 6.42 & $\mathrm{ab}$ \\
\hline $\mathrm{C}=$ Gajah, manure & 1.33 & $\mathrm{a}$ & 2.22 & $\mathrm{a}$ & 2.22 & $\mathrm{a}$ & 3.69 & $\mathrm{a}$ & 5.00 & $\mathrm{a}$ \\
\hline $\begin{array}{l}\mathrm{D}=\text { Merah, mushroom compost } \\
\text { media }\end{array}$ & 1.82 & a & 2.87 & a & 4.08 & $\mathrm{bc}$ & 6.53 & bcde & 7.95 & abc \\
\hline $\mathrm{E}=$ Merah, husk charcoal & 1.97 & $\mathrm{a}$ & 3.72 & $\mathrm{a}$ & 5.83 & $\mathrm{e}$ & 8.92 & $\mathrm{e}$ & 9.28 & cde \\
\hline $\mathrm{F}=$ Merah, manure & 1.17 & $\mathrm{a}$ & 2.33 & $\mathrm{a}$ & 3.83 & $\mathrm{ab}$ & 5.89 & abcd & 8.25 & $\mathrm{bc}$ \\
\hline $\begin{array}{l}\mathrm{G}=\text { Emprit, mushroom compost } \\
\text { media }\end{array}$ & 1.27 & a & 3.14 & a & 5.72 & cde & 7.53 & cde & 10.72 & de \\
\hline $\mathrm{H}=$ Emprit, charcoal husk & 0.00 & $\mathrm{a}$ & 2.50 & $\mathrm{a}$ & 3.00 & $\mathrm{ab}$ & 4.89 & $\mathrm{ab}$ & 7.33 & $\mathrm{abc}$ \\
\hline $\mathrm{I}=$ Emprit, manure & 1.67 & $\mathrm{a}$ & 3.63 & $\mathrm{a}$ & 5.82 & de & 8.05 & de & 11.03 & $\mathrm{e}$ \\
\hline
\end{tabular}

Note: the average number followed by the same letter in the same column is not significantly different according to Duncan's Multiple Range Test at the $5 \%$ level.

Photosynthesis, which will determine the photosynthetic that plants can produce. Photosynthesis is positively correlated with plant productivity [12]. The wider the leaves exposed to sunlight will increase photosynthetic produced by ginger plants. Thus the growth of ginger will be faster and the size of the rhizome becomes larger [11].

\section{E. Stem Diameter}

The composition of the planting media and ginger cultivars significantly affected the stem diameter (Table 5). The results of this study are consistent with the results of research by Aidin, Sahiri, and Madauna [2], which show that the composition of different growing media will pStemuce different stem diameters. The same thing was obtained in Anam's study [9]. Increasing the diameter of the stem is one measure of plant growth. Ginger is a monocot plant so it does not have cambium so that up to a certain age its diameter will not increase again as happened in dicot plants.

TABLE V. EFFECT OF COMPOSITION OF GROWING MEDIA AND GINGER CULTIVATION ON STEM DiAMETER

\begin{tabular}{|l|l|l|l|l|}
\hline \multirow{2}{*}{ Treatment } & \multicolumn{4}{c|}{ Stem Diameter (cm) at age: } \\
\cline { 2 - 5 } & \multicolumn{2}{|c|}{$\mathbf{8 4 \text { DAP }}$} & \multicolumn{2}{c|}{ 98 DAP } \\
\hline $\begin{array}{l}\text { A = Gajah, mushroom } \\
\text { compost media }\end{array}$ & 0.38 & $\mathrm{ab}$ & 4.22 & $\mathrm{a}$ \\
\hline $\mathrm{B}=$ Gajah, husk charcoal & 0.33 & $\mathrm{a}$ & 4.32 & $\mathrm{a}$ \\
\hline $\mathrm{C}=$ Gajah, manure & 0.50 & $\mathrm{abc}$ & 5.30 & $\mathrm{ab}$ \\
\hline $\begin{array}{l}\mathrm{D}=\text { Merah, mushroom } \\
\text { compost media }\end{array}$ & 0.64 & $\mathrm{abcd}$ & 5.96 & $\mathrm{abc}$ \\
\hline $\mathrm{E}=$ Merah, husk charcoal & 0.84 & $\mathrm{~cd}$ & 6.82 & $\mathrm{bcd}$ \\
\hline $\mathrm{F}=$ Merah, manure & 0.54 & $\mathrm{abc}$ & 4.88 & $\mathrm{a}$ \\
\hline $\begin{array}{l}\mathrm{G}=\text { Emprit, mushroom } \\
\text { compost media }\end{array}$ & 0.99 & $\mathrm{~d}$ & 8.49 & $\mathrm{~d}$ \\
\hline $\mathrm{H}=$ Emprit, charcoal husk & 0.59 & $\mathrm{abcd}$ & 7.01 & $\mathrm{bcd}$ \\
\hline $\mathrm{I}=$ Emprit, manure & 0.75 & $\mathrm{bcd}$ & 7.51 & $\mathrm{~cd}$ \\
\hline
\end{tabular}

Note: the average number followed by the same letter in the same column is not significantly different according to Duncan's Multiple Range Test at the 5\% level.

In the three ginger cultivars tested, Emprit which was planted on soil mixed media with mushroom compost media had relatively larger stem diameters compared to the other two cultivars. While Gajahs planted on a mixture of soil with rice husk and Merah charcoal on manure have relatively smaller stem diameters. When seen from Table 5, it seems that the initial growth of Emprit was relatively faster compared to the other two cultivars so that Emprit had a larger stem diameter. Ginger is an annual plant whose growth is relatively slow. The size increase is relatively small so it requires a longer time to find out the size increase. Ginger is usually harvested at 12 months, while young ginger is harvested at 4 months.

\section{CONCLUSION}

- The type of organic material used as a component of the planting medium significantly affected the number of shoots of age, plant height, number of leaves, and stem diameter in the three ginger cultivars tested.

- Mixing the soil with manure provides the best growth in Emprit ginger.

\section{ACKNOWLEDGMENT}

The authors thank the UGJ Research Institute for funding this research.

\section{REFERENCES}

[1] S. Soeparjono, "Pengaruh Komposisi Media Organik Terhadap Pertumbuhan, Hasil dan Kualitas Rimpang Tiga Varietas Jahe (Zingiber officinale Rosc.)," Prosiding Seminar Ilmiah Perhorti 2013, pp. 613618, 2013.

[2] A. Aidin, N. Sahiri, and I. Madauna, "The Effect of Rhizome Types and The Composition of Planting Media on The Growth of Red Ginger (Zingiber Officinale Rosc.) (Pengaruh Jenis Rimpang dan Komposisi Media Tanam Terhadap Pertumbuhan Bibit Jahe Merah)," J. Agrotekbis, vol. 4, no. 4, pp. 394-402, 2016.

[3] B.H. Ali, G. Blunden, M.O. Tanira, and A. Nemmar, "Some phytochemical, pharmacological and toxicological properties of ginger (Zingiber officinale Roscoe): A review of recent research," Food Chem. Toxicol., vol. 46, no. 2, pp. 409-420, 2008.

[4] D. Astriani, W. Dinarto, and W. Mildaryani, "Penerapan Teknologi Tanaman Jahe dan Pengolahan Rimpangnya sebagai Upaya Peningkatan Kesejahteraan Petani di Dusun Sprpgaten dan Kaliberot,” J. AgriSains, vol. 4, no. 7, pp. 56-64, 2013.

[5] H.C. Sari, S. Darmanti, and E.D. Hastuti, "Pertumbuhan Tanaman Jahe Emprit pada Media Tanam Pasir dengan Salinitas yang Berbeda," Bul. Anat. dan Fisiol., vol. 14, no. 2, pp. 19-29, 2011.

[6] S. Pamuji and B. Saleh, "Pengaruh intensitas naungan buatan dan dosis pupuk K terhadap pertumbuhan dan hasil jahe gajah," Akta Agrosia, vol. 13, no. 1, pp. 62-69, 2010. 
[7] P. Hepperly, "Producing Bacterial Wilt-Free Ginger in Greenhouse Culture," Soil Crop Manag., vol. 8, no. June, pp. 1-6, 2004.

[8] S. Suharso, "Pengaruh Macam Konsentrasi Zat Pengatur Tumbuh (ZPT) dan Macam Media Tanam Terhadap Pertumbuhan Bibit Jahe Merah (Zingiber officcinale var. rubrum)," Saintis, vol. 7, no. 2, pp. 137-151, 2015.

[9] C. Anam, "Pengaruh Macam Media Tanam Dan Macam Naungan Terhadap Pertumbuhan Bibit Jahe Merah (Zingiber officinale var. rubrum)," Saintis, vol. 7, no. 2, pp. 123-136, 2015.

[10] E. Enujeke and C. Egbuchua, "Growth and yield responses of ginger (Zingiber officinale) to three sources of organic manures in a typical rainforest zone, Nigeria," J. Hortic. For., vol. 5, no. 7, pp. 109-114, 2013.

[11] S. Samanhudi, A. Yunus, B. Pujiasmanto, and M. Rahayu, "Effect of Organic Manure and Arbuscular Mycorrhizal Fungi on Growth and Yield of Young Ginger (Zingiber officinale Rosc.)," IOSR J. Agric. Vet. Sci., vol. 7, no. 5, pp. 01-05, 2014.

[12] F. Zuhro, Sukamto, and D. Sucianingtyas, "Stem Pruning Techniques Effect for Big Ginger (Zingiber officinale var. officinale) Productivity by Bag Culture Planting System (Pengaruh Teknik Pemangkasan Batang Terhadap Produktivitas Jahe Gajah dengan Sistem Penanaman Bag Culture)," Bioma J. Biol. dan Pembelajaran Biol., vol. 3, no. 1, pp. $22-$ 31, 2018. 